ljaz Uddin

\title{
What determine inflation in Pakistan: an investigation through structural equation modeling by using time series data for a period from 1975 to 2017
}

\section{KEYWORDS}

monetary policy;

output;

interest rate;

MTM;

inflation;

cost channel

demand channel;

structural equation modeling

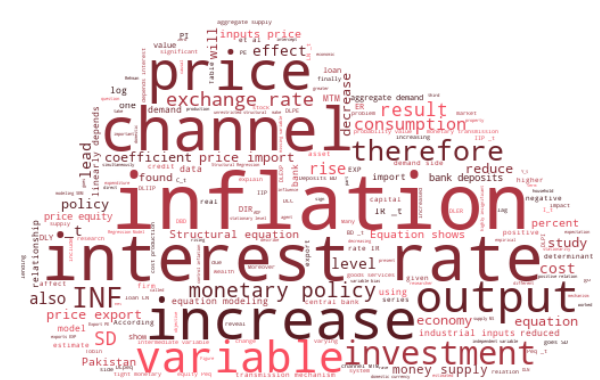

Word Cloud Generated by:

https://wordscloud.pythonanywhere.com/

\section{ABSTRACT}

Interest rate is the most popular instrument of monetary policy to control inflation around the globe. It is assumed that the tight monetary policy, such as an increase in interest rate, will reduce inflation by reducing aggregate demand in the economy. However, in reality, the use of monetary tightening could be counterproductive. The monetary tightening may increase inflation dates back to 1923 when Gibson (1923) observed that correlation between interest rate and inflation is positive.

There are different opinions about how the interest rate affects inflation. The most famous is called Monetary Transmission Mechanism (MTM). According to the demand side channel of MTM, increase an interest rate, therefore the aggregate demand will decrease and finally, the price level will decrease. However, the supply side channel of MTM, states that the rise of interest rate will increase the cost of production, shifting up the aggregate supply curve. This will create a rise in the general prices level.

The problem in that, there are many channels of MTM which can be categorized into demand side and supply side. Many researchers take one channel and make single equation, this leads to missing variable bias. Therefore there is need to take them simultaneously which can be done by (SEM) Structural equation modeling. This research study is very significant, because this research combines both demand and supply channel simultaneously, and removes biasedness through (SEM) structural equation modeling.

The Augmented Dickey-Fuller (ADF) test finds that all the variables are stationary at first difference i.e. I (1), except inflation and investment. Firstly, unrestricted structural equation model (USEM) has estimated. The mostly coefficient of USEM has found to insignificant i.e. their probability value more than 50 percent. To remove the insignificant coefficient, we are given these unnecessary coefficients the regression weight is zero for the purpose of getting significant results. Secondly, the restricted structural equation model (RSEM) is estimated. The estimated results reveal that; interest rate has a positive relation with exchange rate and industrial inputs prices, while negative relation with the price of equity and investment. Therefore, the exchange rate, price of imports, price of exports and consumption have a positive relation with inflation while investment, loan, and output have a negative relationship with inflation.

Finally, the interest rate is not a significant determinant of inflation. Therefore, the exchange rate and cost channel are responsible for the transmission mechanism of interest rate to inflation in Pakistan. This study can be extended in several ways. First, this study focus on how monetary policy effect inflation, further includes in this study fiscal policy. Lastly, a regional analysis can serve as the best extension of this research. Our work was focused on Pakistan only, however a regional comparison can be appropriate.

Uddin, I. (2020). What determine inflation in Pakistan: an investigation through structural equation modeling by using time series data for a period from 1975 to 2017. Economic consultant, 32 (4), 54-72. doi: 10.46224/ecoc.2020.4.6 


\section{INTRODUCTION}

\section{Background of the study}

$\mathrm{T}$ he major objective of the central bank of any country to control inflation and maintain the price stability. To achieve these objectives, the monetary authorities use the policy variables (interest rate and money supply etc.) to control inflation and maintain the price stability. The central bank looks at every other thing but mainly focused on inflation. The Central bank assumes that inflation can be controlled by adopting a tight monetary policy; therefore, they are increasing interest rate to reduce inflation. The standard monetary theory assumes that increasing interest rate to reduce inflation by reducing aggregate demand in the economy. Many central banks are now using Taylor Rule to monitor the interest rate is the major policy variable suggested by this rule.

There are different opinions about how the interest rate affects inflation. The most famous is the so-called Monetary Transmission Mechanism (MTM). According to the demand channel of MTM decrease in money supply will increase the interest rate, therefore the aggregate demand will decrease and finally, the price level will decrease. Most literature worked on the relationship between the interest rate and inflation have focused on Demand-side MTM channel $[6 ; 29]$.

However, there are several other channels to link the interest rate with the level of prices, which show that the rise in interest rate would raise the price level. E.g., cost channel states that the rise of interest rate will increase the cost of production, shifting up the aggregate supply curve. This will create a rise in the general prices level. Many Researcher claims that the rise in interest rate leads to higher inflation; therefore, impacts on the cost side of the economy. The monetary tightening will reduce the aggregate supply and further increase inflation. Therefore, the indication that monetary tightening increases inflation dates back to 1923 when Gibson (1923) fount that the correlation between the inflation and interest rate for UK's historical data is positive. Rehman [6] observed that the rise in interest rate leads to higher inflation; therefore, impacts on the cost side of the economy.

There are different causal channels through which monetary policy can affect the target variables such as interest rate. The most popular of which so called demand channel of monetary transmission mechanism.

The problem in that, there are many channels of MTM which can be categorized into demand side and supply side. Many researchers take one channel and make single equation, this leads to missing variable bias. Therefore there is need to take them simultaneously which can be done by structural equation modeling (SEM).

\section{Objective of the study}

1. To find determinants of inflation using Structural Equation Modeling which takes care of all possible causal channels. 
2. To explore dominant monetary mechanism among the cost side and demand side monetary transmission channels.

\section{Significance of the study}

Different researchers employed different methodologies to empirically investigate the causes, effects, and determinants of inflation. The researcher takes one channel for inflation demand or supply and makes single equation model, but not combines channels which leads to biased results. This research study is very significant and important, because this research combines both demand and supply channel simultaneously, and removes biasedness through (SEM) structural equation modeling. Moreover this empirical study will be helpful for the monetary policy of Pakistan to adopt the correct policy to control inflation.

\section{The monetary transmission mechanism}

Monetary policy affects the economy and the price level through several channels. The rule by which monetary policy decisions are transferred to the real economy is called the monetary transmission mechanism (MTM). The MTM is the most famous mechanism of the economy. Therefore, how varying in the central bank policy rate are transferred through the economy influencing, aggregate supply and aggregate demand, and inflation rate.

\section{Channels of Monetary Transmission Mechanism:}

The monetary transmission mechanism (MTM) has six channels includes; (1) Interest rate channel, (2) Credit Channel (3) Assets Price Channel, (4) Exchange rate Channel, (5) Expectation Channels (6) Cost Channels. These channels are pictured in figure one. The details of these channels are mentioned below:

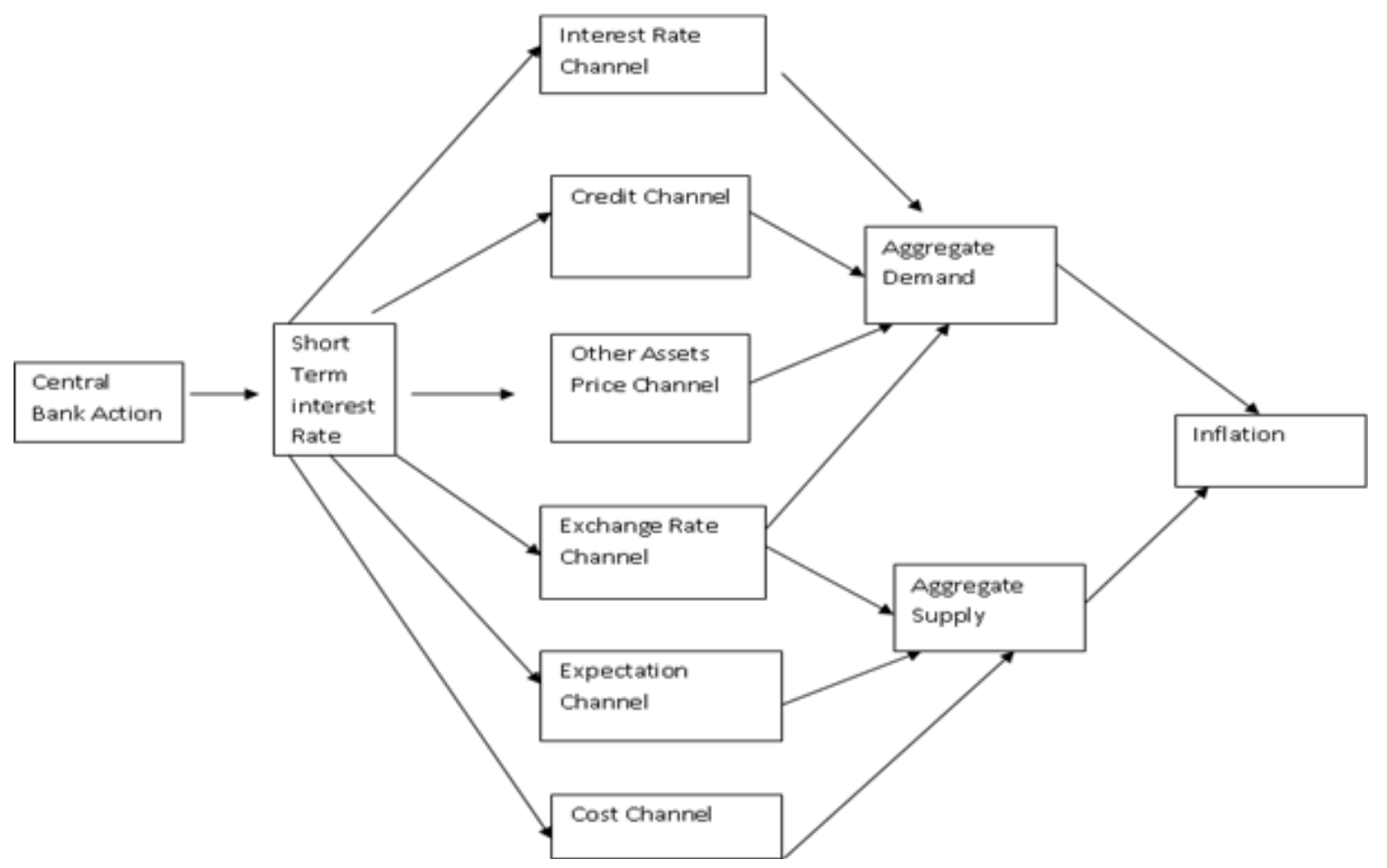

Figure 1 Channels of MTM (Source: Ghafari \& Rehman (2013)) 


\subsection{Interest Rate Channel}

In this channel the rising interest rate has negative impact on output and inflation. This is because when central bank increase policy rate $(i \uparrow)$ consequently rising cost of capital, hitting a brake on investment $(I \downarrow)$. Furthermore, increasing saving and consumption decreasing $(I \downarrow)$ thereby the aggregate demand to weaken $(\mathrm{\downarrow} \downarrow)$. Moreover, the interest rate has negative relation with investment as well as output of the economy. Smets and Wouters found that the interest rate channel has an effect on consumption, investment demand and real output for the euro area countries. When aggregate demand sinks below aggregate supply, the expected finding is downward pressure on prices, and therefore inflation is reduce $(\varpi \downarrow)$.

$$
\mathrm{M} \downarrow=>\mathrm{i} \uparrow=>\mathrm{r} \uparrow=>\text { cost of capital } \uparrow=>I \downarrow=>C \downarrow=>Y \downarrow=>\pi \downarrow
$$

\subsection{Credit Channel}

The second channel of MTM is called the credit channel. The fluctuations in interest rate have an impact on the supply of credit. Bernanke divided credit channel into two types; firstly bank lending and secondly balance sheets channels.

\section{2 (a)The Bank Lending Channel (the narrow credit)}

The bank lending channel hypothesizes that varying in monetary policy will shift the supply of credit, especially credit reached within commercial banks. The Monetary policy actions may influence the supply of loanable funds accessible to banks, bank's liabilities, and consequently the total amount of loans they can make a bank's assets.

$$
\mathrm{M} \downarrow=>\mathrm{i} \uparrow=>\text { bank deposits } \downarrow=>\text { bank loans } \downarrow=>I \downarrow=>C \downarrow=>\mathrm{Y} \downarrow
$$

Where $(M \downarrow)$ shows a tight monetary policy to an increase in real interest rate (i $\uparrow$ ), impact on slowdown of the bank deposits (BD $\downarrow$ ), therefore causing a reduce a bank loan, ultimately investment expenditure $(I \downarrow)$, and consumption pattern of household also $(C \downarrow)$, leading to decline in aggregate demand and output level go down $(\mathrm{Y} \downarrow)$, Monetary policy influences bank deposits, leading to varying in the amounts of bank loans, investment, and output.

\section{2 (b) Balance Sheet Channels}

This channel of the MTM refers to the role of the financial condition of private agents plays in the MTM. It occurs because the changes in policy not only influence the market interest rates but also the financial position of private agents because varying the policy rate affect consumers, cash follows the net worth of companies and bank balance sheets. Higher interest rates $(\mathrm{i} \uparrow)$ result in reduced cash flow, and reduced net worth of the banks, therefore adverse selection and moral hazard increased $(\uparrow)$. Hence the drop in loans, thus decrease in lending. If lending goes down the investment is reducing $(I \downarrow)$ and finally decline in aggregate output $(Y \downarrow)$.

$$
\mathrm{M} \downarrow=>\mathrm{i} \uparrow=>\text { adverse selection \& moral hazards } \uparrow=>\text { lending } \downarrow=>\mid \downarrow=>\mathrm{Y} \downarrow
$$

\subsection{Other Asset Price Channel}

The third channel of MTM, concentrate on other asset price channel. This channel reveals, 
how the monetary policy determine domestic asset prices; such as real estate prices, stock market, and bond. Furthermore, a variation in the securities prices creates a variation in wealth which can influence household consumption.

Tobin's q Channel: $q=M V F / R C C$

Where the market value of firms (MVF) and replacement cost of capital (RCC). The Tobin q Ratio shows the relationship between intrinsic value and market valuation. In other terms, intend to estimate whether a provided business or market is undervalued or undervalued. When the Tobin q value is lies between ( 0 and 1 ) suggest that the stock is undervalued, this is because of, and the cost to replace a firm's assets is higher than the value of its stock. On the contrary, when the Tobin $q$ is higher than 1, indicate that the stock is overvalued because a firm's stock is more costly than the replacement cost of its assets.

\section{3 (a) Equity Price effects on investment}

When Central bank used tight (i $\uparrow$ ) monetary policy that leads to decrease equity prices. The Tobin $q$ value of $(q \downarrow)$ is reducing, therefore the stock market value of firm capital reduces as result firms do-not issue new equities which reveal to reduce investment $(I \downarrow)$, the aggregate demand is also decreasing $(Y \downarrow)$.

$$
\mathrm{M} \downarrow=>\mathrm{i} \uparrow=>\mathrm{P}_{\mathrm{e}} \downarrow=>\mathrm{q} \downarrow=>I \downarrow=>\mathrm{Y} \downarrow
$$

\section{3 (b) Wealth effects on consumption}

Wealth effect is introduced by Norrbin in his famous "life cycle hypothesis of consumption", argue that the consumption is the most important mechanism. According to Modigliani found that when policy rate increase lead to reduce household long term assets, therefore the household wealth reduce, which more reduce consumption expenditure and the output. Considering that tight monetary policy stock prices, the wealth transmission mechanism works as follows:

$$
\mathrm{M} \downarrow=>\mathrm{i} \uparrow=>\mathrm{P}_{\mathrm{e}} \text { equity, property \& land } \downarrow=>\mathrm{W} \downarrow=>\mathrm{C} \downarrow=>I \downarrow=>\downarrow
$$

Tobin's $q$ and wealth mechanisms allow for a general definition of equity that includes properties and land. For example, a decrease in property prices, which reduce their value relative to replacement cost, therefore decrease Tobin's q for the property, thereby decreasing its production. Also, a decrease in property and land prices, its result wealth reduce $(\mathrm{W} \downarrow)$, thereby reduce consumption $(C \downarrow)$ and output $(\mathrm{V} \downarrow)$.

\subsection{Exchange Rate Channel}

The exchange rate channel explains how monetary policy changes the strength of the currency. the monetary policy rises the policy rate reaches to a strengthening of the domestic currency. The exchange rate effects inflation through varying in the domestic prices of goods for the rest of another country trade. The low payment on imports in this way inflation is controlled. The economy is effected through exchange rate channel via demand side and supply side respectively. 
The demand side, the rise of interest rate $(i \uparrow)$, leads appreciate the domestic currency. The price of domestic goods increased (Pdg), the exports are reduced and finally net exports also $(\mathrm{NX} \downarrow)$ decreased. When the net exports go down the output is also $(\mathrm{Y} \downarrow)$ goes down.

$$
\mathrm{M} \downarrow=>\mathrm{i} \uparrow=>\mathrm{E} \downarrow=>\mathrm{P}^{\mathrm{dg}} \uparrow \Rightarrow \mathrm{P}^{\mathrm{fg}} \downarrow=>\mathrm{NX} \downarrow=>\mathrm{Y} \downarrow=>\pi \uparrow
$$

The supply side, central bank used loose (i $\downarrow$ ) monetary policy, To decrease the nominal interest rate which further decreases the real interest as a result domestic currency depreciates due to uncovered interest rate parity. If currency is depreciate ultimately exchange rate increased $(\mathrm{E} \uparrow)$, lead to increases firm's cost of production and $(\mathrm{r} \uparrow)$ retail prices of import prices based goods and services and also increase the price of ( $\mathrm{P}^{\mathrm{fg}} \uparrow$ ) imported prices. which further decreases aggregate demand and $(\mathrm{Y} \downarrow)$ output and finally increased inflation $(\varpi \uparrow)$.

$$
\mathrm{M} \uparrow=>\mathrm{i} \downarrow=>\mathrm{E} \uparrow=>\mathrm{r} \uparrow=>\mathrm{P}^{\mathrm{dg}} \downarrow=>\mathrm{P}^{\mathrm{fg}} \uparrow=>\mathrm{Y} \downarrow=>\pi \uparrow
$$

\subsection{Expectation Channel}

Inflation expectations are the main way for companies and firms to set their prices and wages formation function for their employers and thus inflation. This channel is a very significant role in determining the current as well as future levels of output production. The increasing policy rate is also changing the behavior of the economic agents. If the behavior of the economic agent's changes the economic activity is also varying and prices, this is because of expectation.

\subsection{Cost Channel}

This is the last channel of MTM. Normally the researcher reflects that inflation can be controlled by adopting the tight monetary policy. Goes up policy rate leads to also go up cost of working capital, indusial inputs prices and general cost of production are increasing. Therefore, the marginal cost of the firms also rises. When MC goes up the output of the firms are decreasing and finally, inflation is increase.

$$
\mathrm{M} \downarrow=>\mathrm{i} \uparrow=>\text { cost of working capital } \uparrow=>M C \uparrow=>\text { cost of production } \uparrow=>Y \downarrow=>\pi \uparrow
$$

Where $(M \downarrow)$ shows a tight monetary policy driving to an increase in real interest rate (i $\uparrow$ ), impact on boosts the cost of production, therefore causing a decline in aggregate demand and output level go down $(\mathrm{Y} \downarrow)$, and ultimately $(\varpi \downarrow)$ inflation is decreasing.

\section{LITERATURE REVIEW}

\section{Demand Side Channel of MTM}

Demand side inflation occurs when the aggregate demand is more than aggregate supply therefore prices go up. According to [15] investigated the relationship between monetary policy and inflationary pressure in Pakistan by using ARDL. Annual data was selected from 1973 to 2013. They found that Money supply is an important variable of controlling inflation. Ahmed [37] examined Inflation and their determinants in case of Pakistan, from 1971 to 2012 by applying Johansen Co-Integration Approach. They also found that money supply and inflation 
had positive relation with each other, if 10 percent increase in money supply causes 6.9 percent rise an inflation. There result support demand-side inflation. According to [26] money supply effects all indicators of inflation.

Speedy rising in the population leads to increase in prices. When the population increase, demand for goods and services also rises. If demand rises but supply is constant, it creates unbalance between supply and demand. This leads to demand pull inflation. Adam worked on cross country and U.S metro, using panel regressions analysis. They found population growth was negatively related to inflation. One percent reduction in population growth decreases inflation by one third to two third percent. According to [13] indicated that, population growth rate is major determinants of unemployment and inflation.

\section{Cost Channel of MTM}

In the long run, rising Imports of goods and services will adversely affect investment. The price level increases if a deficiency of aggregate demand in the economy. Therefore, the imports prices increase due to higher demand for imported goods i.e. (raw materials, machinery, technology, etc.) resulting the price level increase [9] analyzed determinants of inflation in Turkey. The coefficient of import price, was positive meaning that, import prices had positive relation with inflation. By using Johannes cointegration utilizing by [37] found that import of goods and services was the main reason of inflation. The study of [26] suggested that imports were directly related to all price indicators (WPI, SPI, CPI, and GDP Deflator). Arif \& Ali [2] worked on Bangladesh economy and found in long run import of goods and services had direct effect on inflation.

Aggregate supply is an important reason for inflation. While the view of new Keynesian is when government expenditure are more than their revenue, the government takes deficit financing, therefore, prices level increases and also inflation occurs. Moreover, inflation expectation increases if upgrade level of government debt. Bashir [9] found the cast went up the goods and services, when refunded the debt. Umaima and Yasmin examine the effect of public expenditure on the whole economic activity. Their result showed that public debt leads to fiscal expansion leading to a greater vulnerability of raising inflation which further leads to the higher interest rate. Khan et al., [33] found that public sector borrowing had a direct effect on inflation in Pakistan.

Our export is less than imports, so when the exchange rate falls (depreciate domestic currency) therefore imports prices increases, but the net exports reduce. Mbongo et al. examined effect of money supply on inflation in Tanzania from 2000 to 2011. They found, 1 percent decrease of exchange rate against US dollar pushed 0.3 percent of inflation in Tanzania. Moreover, exchange rate and money supply directly related to inflation. The study conducted by Alexander et al. in Nigeria found in both fiscal and monetary policy affect inflation. Moreover, exchange rate influenced inflation in long run. Present year real exchange rate in Dollar reduced inflation. While former year real exchange rate increased inflation rate. 


\section{Structural Equation Modeling}

Many literatures worked on Determinants of inflation? Either using simple regression or VAR and SVAR, but this empirical study justify the methodological gap by answering the above question using a various approach. A VAR system is a multi-equation system there is one equation for each variable being examined. Each variable is explained by its lags and all the lags of all the other variables. The SVAR is the simultaneous family, which explores cause and effect relationship, which display the effect of structural shocks on selected variables by using impulse response function. The problem is generating in SVAR the structural shocks is not random, but this is already in the part of existing information. Also in the conventional technique, there is creating a problem of Missing variable bias. Because of this weakness in the above given traditional approach. The present study answers 'Determinants of inflation? Using structural equation Modeling (SEM).

\section{MATERIALS AND METHODS}

It is of immense importance to empirically test the theoretical underpinnings. Without empirical testing, one cannot be sure that whether theory is correct or not. To estimate the model, one need data and has to specify an estimation technique.

\section{Structural Equation Modeling (SEM)}

The relationship between inputs of monetary policy and output, it cannot be described as a single equation relation. There are number of transmission channels, which transmit the effect of monetary policy variables to the target variables through a separate set of intermediate variables. Each of the policy's inputs described above, effects intermediate variable which simultaneously impact output variables. Therefore, a system of equations is needed to describe relation between monetary policy's inputs and inflation. If any one of the equations from a system of equations is estimated by ignoring the others, then the estimates are subject to missing variable bias.

Therefore, we have chosen Structural Equation Modeling for quantifying the relation between monetary policy and inflation. The structural equation modeling is capable of estimating the system of equation such as the above mentioned system can be estimated simultaneously without the endogeneity or missing variable bias. Structural equation modeling (SEM) is a multivariate statistical technique that is applied to explain the relationship among multiples variables. It investigates the structural relationships expressed in a series of the equation, alike, to multiple regression analysis.

\section{Variables of Monetary Transmission Mechanism (MTM)}

There is a causal chain of monetary policy impacting inflation through different channels. We will use three types of variables. 


\subsection{Inputs variables}

Input variables mean the input of monetary policy. These are inputs of monetary policy, namely interest rate (IR) and money supply (MS).

\subsection{Intermediate variables}

Intermediate variables are those variables which have a relationship with output variables but are not direct inputs of monetary policy. These variables are not the direct input of monetary policy, rather these are consequences of the inputs of monetary policy and may affect the output variables. These include i.e. Exchange rate (ER), Price of imports (PI), Price of Export (PE), exports (EXP), consumption (c), Bank Deposits (BD), Investment (I), loan (LN), Output (Y), Price of equity (Peq), Industrial inputs prices (IIP).

\subsection{Output variables}

Output variables; which are Inflation (INF). In Figure 2 explains how input variables affect intermediate variables and then output variables. It includes all variables explain above.

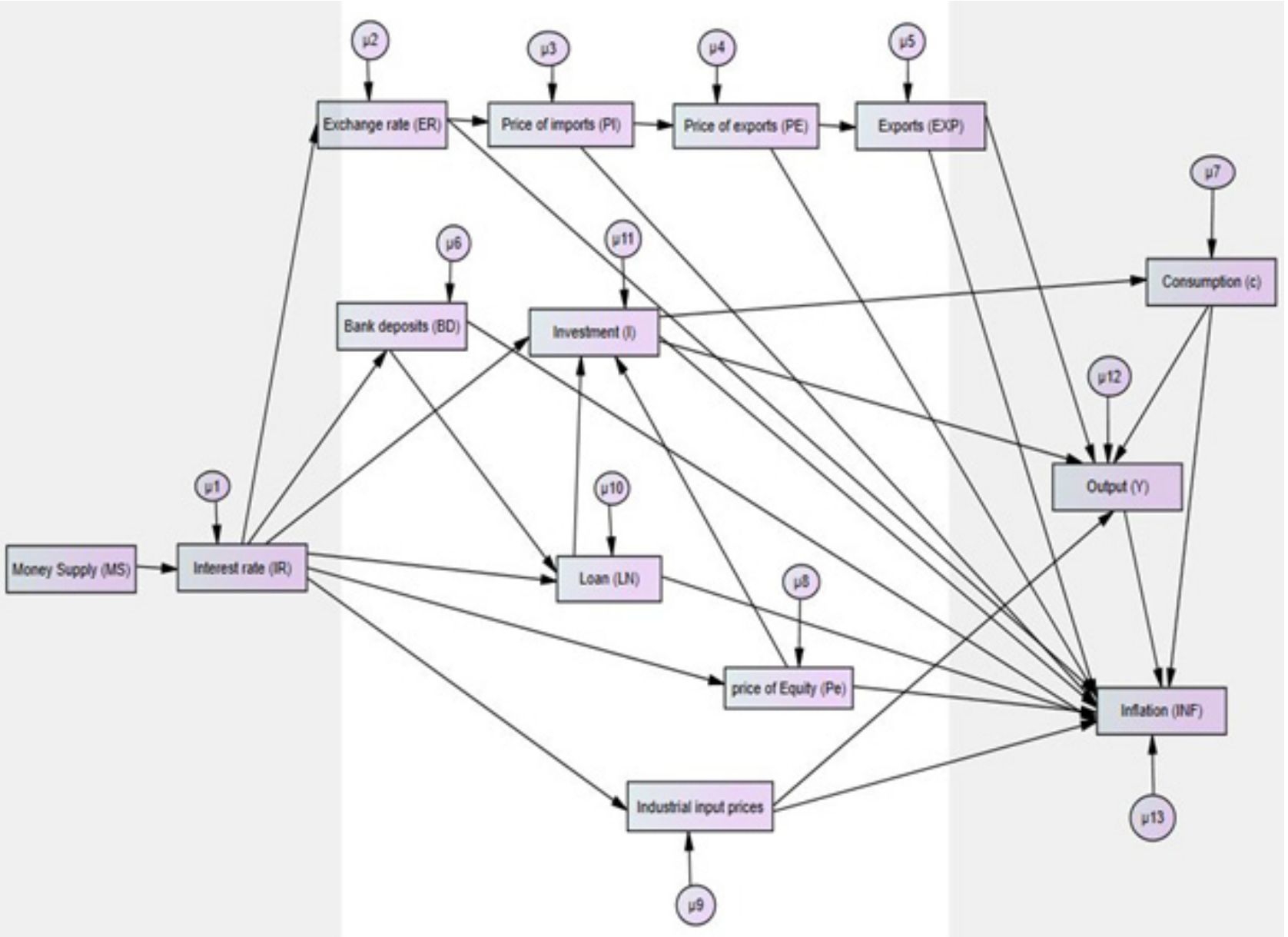

Figure 2 Path Diagram of MTM (Source: Author's own drawing based on theoretical models)

In figure 2, cover many channels of MTM the demand channel and supply channels. The causal paths describes - equations (1 to 13) can be written in the following equation:

Equation (1) describes that interest rate (IR) linearly depends on Money supply (MS) i.e. 
$I R_{t}=\beta_{11} M S_{t}+U_{1 t}$

Equation (2) describes that Exchange rate (ER) linearly depends on interest rate (IR) i.e.

$E R_{t}=\beta_{21} I R_{t}+U_{2 t}$

Equation (3) explains that Price of import (PI) linearly depends on Exchange rate (ER) i.e.

$P I_{t}=\beta_{31} E R_{t}+U_{3 t}$

Equation (4) explains that Price of Export (PE) linearly depends on Price of import (PI) i.e.

$P E_{t}=\beta_{41} P I_{t}+U_{4 t}$

Equation (5) shows that export (EXP) linearly depends on Price of Export (PE) i.e.

$\mathrm{EXP}_{\mathrm{t}}=\beta_{51} \mathrm{PE}_{\mathrm{t}}+\mathrm{U}_{5 \mathrm{t}}$

Equation (6) shows that Bank Deposits (BD) linearly depends on interest rate (IR) i.e.

$B D_{t}=\beta_{61} I R_{t}+U_{6 t}$

Equation (7) shows that consumption (C) linearly depends on investment (I) i.e.

$C_{t}=\beta_{71} I_{t}+U_{7 t}$

Equation (8) shows that Price of equity (Peq) linearly depends on interest rate (i) i.e.

$P e q_{t}=\beta_{81} I R_{t}+U_{8 t}$

Equation (9) shows that industrial inputs prices (IIP) linearly depends on interest rate (IR) i.e.

IIP $=\beta_{91} I R_{t}+U_{9 t}$

Equation (10) shows that Loan (LN) linearly depends on interest rate (IR), Bank deposits i.e.

$L N_{t}=\alpha_{11} I R_{t}+\alpha_{12} B D_{t}+U_{10 t}$

Equation (11) shows that Investment (I) linearly depends on interest rate (IR), Loan (LN) price of equity (Peq) i.e.

$I_{t}=\alpha_{21} I R_{t}+\alpha_{22} L N_{t}+\alpha_{23} P_{e q}+U_{11 t}$

Equation (12) shows that Output (Y) linearly depends on exports (EXP), consumption (C), Investment (I), industrial inputs prices (IIP) i.e.

$Y_{t}=\alpha_{31} E X P_{t}+\alpha_{32} C_{t}+\alpha_{33} I_{t}+\alpha_{34} I I P_{t}+U_{12 t}$

Equation (13) will show the linear regression of output variable inflation (INF) and all the intermediate variables i.e. Interest rate (IR) have linear relation with intermediate variables i.e.

Exchange rate $(E R)$, price of imports $(\mathrm{PI})$, price of exports (PE), Exports (EXP), bank deposits (BD), investment (I), consumption (c), price of equity (Peq), loan (LN), Industrial inputs prices (IIP), and Output (Y) i.e.

$$
\begin{aligned}
& I N F_{t}=\alpha_{40} E R_{t}+\alpha_{41} P I_{t}+\alpha_{42} P E_{t}+\alpha_{43} E X P_{t}+\alpha_{44} B D_{t}+\alpha_{45} I_{t}+\alpha_{46} C_{t}+\alpha_{47} P e q_{t}+ \\
& +\alpha_{48} L N_{t}+\alpha_{49} I I P_{t}+\alpha_{50} Y_{t}+U_{13 t}
\end{aligned}
$$

\section{Augmented Dickey-Fuller Test}

The rationale of the ADF test is the violation of the Assumption in DF Test. If there is a serial correlation problem in the data generating process of the DF test, then we apply the Augmented Dicky fuller Test to detect the stationarity in the data series. So to deal with this problem we introduce the lag of the dependent variable as an independent variable in the model until the problem of serial correlation is removed. To check the stationarity of variables we will apply the Augmented Dickey-Fuller Test. So the equation we estimate after introducing 
lag of dependent variables as independent variables is known as Augmented Dickey-Fuller $(\mathrm{ADF})$ regression:

$$
\Delta X_{t}=\theta+\beta_{t}+\rho X_{(t-1)}+\sum I_{i}=1 \beta i \Delta X_{(t-i)}+u_{t}
$$

In the given equation (14), the $\Delta X_{t}$ is the dependent variable represents first

difference of the data series. The independent variables of the series which are $\theta, \beta_{t}, \rho, \beta_{i}$ and $u_{t}$. The $\theta$ is the constant term, $\beta_{t}$ represent trend of the data series, $\rho$ shows slope of the first difference of $X_{t}$ series, $\beta$, represent coefficient of the $i$ lags of the 1 series and $u_{t}$ is the error term respectively. The ADF applicable if there error term is white noise i.e. $u_{t} \sim N(0, \sigma 2)$.

\section{RESULTS}

The fundamental objective of the present study is answering a question: what determine inflation in Pakistan? The question is modeled by using structural equation modeling. The following are the main results.

\section{Results of Unit root test}

In order to Avoid Spurious Results, before the estimation whether data is stationary or not? All the variables are transformed into logarithmic form, except inflation, investment and interest rate before applying the unit root test. The Null hypothesis of the ADF test is non stationary, while Alternative hypothesis the data is stationary. The variable of the study included; Money supply (MS), interest rate (IR), Exchange rate (ER), Price of imports (PI), Price of Export (PE), export (EXP), consumption (c), Bank Deposits (BD), Investment (I), loan (LN), Output (Y), Price of equity (Peq), Industrial inputs prices (IIP), and inflation (INF). The ADF results are given below:

Table 1

Results of ADF unit root test

\begin{tabular}{|l|c|c|c|c|c|}
\hline & Intercept & Trent \& intercept & Intercept & Trent \& intercept & Level of integration \\
\hline LMS & -1.21 & -2.81 & $-5.42^{* * *}$ & $-5.36^{* * *}$ & $\mathrm{I}(1)$ \\
\hline IR & -1.6 & -1.64 & $-5.39^{* * *}$ & $-5.45^{* * *}$ & $\mathrm{I}(1)$ \\
\hline LER & -0.34 & -2.21 & $-4.36^{* *}$ & $-4.29^{* * *}$ & $\mathrm{I}(1)$ \\
\hline LPE & -1.88 & -1.65 & $-5.38^{* * *}$ & $-5.67^{* * *}$ & $\mathrm{I}(1)$ \\
\hline LPI & -0.71 & -1.99 & $-4.89^{* * *}$ & $-4.81^{* * *}$ & $\mathrm{I}(1)$ \\
\hline LEXP & -1.59 & -2.05 & $-7.19^{* * *}$ & $-7.14^{* * *}$ & $\mathrm{I}(1)$ \\
\hline LC & -0.43 & -1.61 & $-5.19^{* * *}$ & $-5.11^{* * *}$ & $\mathrm{I}(1)$ \\
\hline I & $-3.23 * *$ & $-3.37^{*}$ & -- & - & $\mathrm{I}(0)$ \\
\hline LBD & -1.63 & -3.05 & $-5.11^{* * *}$ & $-4.99^{* * *}$ & $\mathrm{I}(1)$ \\
\hline LLN & -1.19 & -2.02 & $-5.53^{* * *}$ & $-5.59^{* * *}$ & $\mathrm{I}(1)$ \\
\hline LY & -0.94 & -2.25 & $-5.45^{* * *}$ & $5.37^{* * *}$ & $\mathrm{I}(1)$ \\
\hline LPeq & -1.88 & -1.65 & $-5.38^{* * *}$ & $-5.67^{* * *}$ & $\mathrm{I}(1)$ \\
\hline LIIP & -1.66 & -1.95 & $-6.04^{* * *}$ & $-5.98^{* * *}$ & $\mathrm{I}(1)$ \\
\hline INF & $-3.714358^{*}$ & $-3.674151^{* *}$ & - & - & $\mathrm{I}(0)$ \\
\hline
\end{tabular}

Note: $* * *, * * *$ indicates significance at $10 \%, 5 \%, 1 \%$ 
Table 2 present the (ADF) Augmented dickey fuller test. At level mean an original data while 1 st difference mean the 1 st lag of the series. The variable LMS (log of Money supply), IR (interst rate), LER (log of exchange rate), LPE (log of price of exports), LPI (log of price of imports), LEXP (log of exports), LC (log of consumption), LBD (log of bank deposits), LLN (log of loans), LY (log of output), LPeq (log of price of equity), and LIIP (log of industrial inputs prices) are nonstationary at level but are stationary at the 1 st difference, hence I (1). While I (investment), and INF (inflation) are stationary at level, i.e. I (0).

\section{Results of Unrestricted Structural Regression Model}

After testing stationarity of the variables. We know all variables of non-stationary at level i.e. I (0) except inflation and investment. To avoid spurious regression and taking meaningful conclusion. We are taking first difference of all the variables, except inflation rate and investment. Now the unrestricted structural equation model are to be estimated to answer the research questions. Unrestricted structural equation model in which all the independent variable are included in the model (stack, 2018). Thirteen equation would be estimated and the results for each model are summarized below:

Table 2

Result of Unrestricted Structural Model

\begin{tabular}{|c|c|c|c|c|c|c|c|}
\hline \multicolumn{7}{|c|}{ Unstandardized Coefficient } & \multirow{2}{*}{$\begin{array}{c}\text { Standardized Coefficient } \\
\text { Estimate }\end{array}$} \\
\hline & & & Estimate & S.E. & C.R. & P.value & \\
\hline DIR & $<--$ & DLMS & -1.168 & 4.389 & -.266 & .790 & -.042 \\
\hline DLER & $<---$ & DIR & .004 & .005 & .797 & .426 & .123 \\
\hline DBD & $<--$ & DIR & -.059 & .144 & -.409 & .683 & -.064 \\
\hline DLPI & $<--$ & DLER & -1.247 & .287 & -4.348 & 0.001 & -.562 \\
\hline DLN & $<--$ & DBD & .069 & .120 & .578 & .563 & .092 \\
\hline DLpeq & $<---$ & DIR & -.033 & .021 & -1.570 & .116 & -.238 \\
\hline DLN & $<--$ & DIR & -.071 & .145 & -.488 & .625 & -.060 \\
\hline DLPE & $<--$ & DLPI & .256 & .137 & 1.868 & .062 & .280 \\
\hline I & $<---$ & DIR & -.764 & .156 & -4.891 & 0.001 & -.605 \\
\hline I & $<---$ & DLN & .080 & .099 & .806 & .420 & .125 \\
\hline 1 & $<--$ & DLpeq & .320 & .857 & .374 & .708 & .059 \\
\hline DLEXP & $<---$ & DLPE & .756 & .082 & 9.195 & 0.001 & .820 \\
\hline $\mathrm{DLC}$ & $<--$ & 1 & .016 & .009 & 1.749 & .080 & .263 \\
\hline DLIIP & $<---$ & DIR & .037 & .026 & 1.415 & .157 & .216 \\
\hline DLY & $<---$ & DLEXP & .002 & .002 & .634 & .526 & .027 \\
\hline DLY & $<--$ & DLC & .868 & .040 & 21.930 & 0.001 & .939 \\
\hline DLY & $<--$ & DLIIP & -.028 & .010 & -2.731 & .006 & -.113 \\
\hline DLY & $<---$ & I & .100 & .027 & 3.665 & 0.001 & .151 \\
\hline INF & $<---$ & DLY & -1.017 & .374 & -2.718 & .007 & -.308 \\
\hline INF & $<--$ & DLEXP & 10.242 & 21.678 & .472 & .637 & .189 \\
\hline INF & $<---$ & DLPE & .625 & .364 & 1.719 & .086 & .234 \\
\hline INF & $<---$ & DLPI & 5.350 & 4.404 & 1.215 & .224 & .163 \\
\hline INF & $<---$ & DLER & 24.951 & 9.513 & 2.623 & .009 & .342 \\
\hline
\end{tabular}




\begin{tabular}{|l|l|l|r|r|r|r|r|}
\hline INF & $<---$ & I & -3.259 & 1.928 & -1.690 & .091 & -.183 \\
\hline INF & $<---$ & DLC & 11.636 & 7.720 & 1.507 & .132 & .299 \\
\hline INF & $<---$ & DLpeq & -8.044 & 23.975 & -.336 & .737 & -.137 \\
\hline INF & $<---$ & DLIIP & 1.874 & 1.698 & 1.104 & .270 & .130 \\
\hline INF & $<---$ & DBD & 1.780 & 6.854 & .260 & .795 & .050 \\
\hline INF & $<---$ & DLN & -.465 & .289 & -1.609 & .108 & -.220 \\
\hline
\end{tabular}

Table 2, shows the result of unrestricted structural regression model (USEM). The above table highlighted rows are highly insignificant, there probability value in more than 50 percent. The insignificant coefficient of the variables includes; money supply, interest rate, Bank deposits, price of equity, and Exports.

\section{Result of Restricted Structural Equation Model}

Restricted Structural Regression Model is one in which coefficient of some independent variable are assume to be zero. This is because in present study the highly insignificant probability value i.e. p.value $>0.50$ percent, are removed from the above model. The result Restricted Structural Regression Model (RSEM) are given below:

Table 3

Result of Restricted Structural Model

\begin{tabular}{|c|c|c|c|c|c|c|c|}
\hline \multicolumn{7}{|c|}{ Unstandardized Coefficient } & \multirow{2}{*}{$\begin{array}{c}\text { Standardized Coefficient } \\
\text { Estimate }\end{array}$} \\
\hline & & & Estimate & S.E. & C.R. & P.value & \\
\hline DIR & $<---$ & DLMS & .000 & & & & .000 \\
\hline DLER & $<---$ & DIR & .004 & .005 & .797 & .426 & .123 \\
\hline DBD & $<---$ & DIR & .000 & & & & .000 \\
\hline DLPI & $<---$ & DLER & -1.247 & .287 & -4.348 & 0.001 & -.562 \\
\hline DLN & $<---$ & DBD & .000 & & & & .000 \\
\hline DLpeq & $<---$ & DIR & -.033 & .021 & -1.570 & .116 & -.238 \\
\hline DLN & $<---$ & DIR & .000 & & & & .000 \\
\hline DLPE & $<---$ & DLPI & .256 & .137 & 1.868 & .062 & .280 \\
\hline I & $<---$ & DIR & -.764 & .156 & -4.891 & 0.001 & -.605 \\
\hline I & $<---$ & DLN & .077 & .099 & .772 & .440 & .120 \\
\hline 1 & $<---$ & DLpeq & .000 & & & & .000 \\
\hline DLEXP & $<---$ & DLPE & .756 & .082 & 9.195 & & .820 \\
\hline DLC & $<---$ & 1 & .016 & .009 & 1.750 & .080 & .263 \\
\hline DLIIP & $<---$ & DIR & .037 & .026 & 1.415 & .157 & .216 \\
\hline DLY & $<---$ & DLEXP & .000 & & & & .000 \\
\hline DLY & $<---$ & DLC & .872 & .038 & 22.738 & 0.001 & .944 \\
\hline DLY & $<---$ & DLIIP & -.027 & .010 & -2.693 & .007 & -.112 \\
\hline DLY & $<---$ & 1 & .100 & .027 & 3.665 & 0.001 & .151 \\
\hline INF & $<---$ & DLY & -1.017 & .374 & -2.718 & .007 & -.308 \\
\hline INF & $<---$ & DLEXP & .000 & & & & .000 \\
\hline INF & $<---$ & DLPE & .625 & .364 & 1.719 & .086 & .234 \\
\hline INF & $<---$ & DLPI & 7.699 & 4.596 & 1.675 & .094 & .246 \\
\hline
\end{tabular}




\begin{tabular}{|l|l|l|r|r|r|r|r|}
\hline INF & $<---$ & DLER & 12.537 & 10.023 & 1.251 & .211 & .180 \\
\hline INF & $<---$ & I & -2.915 & 2.030 & -1.436 & .151 & -.171 \\
\hline INF & $<---$ & DLC & 11.636 & 7.720 & 1.507 & .132 & .299 \\
\hline INF & $<---$ & DLpeq & .000 & & & & .000 \\
\hline INF & $<---$ & DLIIP & 3.238 & 1.645 & 1.968 & .049 & .235 \\
\hline INF & $<---$ & DBD & .000 & & & & .000 \\
\hline INF & $<---$ & DLN & -.401 & .305 & -1.315 & .188 & -.198 \\
\hline
\end{tabular}

Table 3, shows the (RSEM), the above table few highlighted rows are insignificant coefficient which are restricted.

In given table (4), see standardize coefficient, the standardized coefficients of estimation equations (1 to 13) are given below:

$$
\begin{aligned}
& I R_{t}=0.00 M S_{t}+U_{1 t} \\
& E R_{t}=0.123 I R_{t}+U_{2 t} \\
& P I_{t}=-0.562 E R_{t}+U_{3 t} \\
& P E_{t}=0.280 P I_{t}+U_{4 t} \\
& E X P_{t}=0.820 P E_{t}+U_{5 t}
\end{aligned}
$$

In given Equation (1) the Money supply (MS) coefficient $\beta_{11}=0$, this is because there probability value is greater than 50 percent which is highly insignificant. In equation (2), the interest rate goes up by 1 SD, the Exchange rate goes up by 0.123 SD. When interest rate increases its lead to appreciate domestic currency, there for more interest rate appeal to foreign capital and accelerate exchange rate. Equation (3), the exchange rate gives a negative impression on the price of imports that is economically not true. The price of imports would reduce by 0.562 SD due to 1 SD higher exchange rate in Pakistan. The results of Equation (4) of the study reveal that the price of imports is found to be directly related to the price of exports in Pakistan. The coefficient is signifying 0.280 SD rise in the price of exports due to a one percent increase in the price of imports. When the price of imports rises the price of exports also rises because in Pakistan imports are more than exports. Therefore, Pakistani people used imported technology its result the cost of production increases and the price of export also increase. Equation (5) shows that, when the price of export goes up by 1 SD, exports go up by 0.82 SD. The price of export has a positive relation with exports, this is economically not true.

$$
\begin{aligned}
& B D_{t}=0.00 I R_{t}+U_{6 t} \\
& C_{t}=0.263 I_{t}+U_{7 t} \\
& P e q_{t}=-0.238 I R_{t}+U_{8 t} \\
& I I P_{t}=0.216 I R_{t}+U_{9 t} \\
& L N_{t}=0.00 I R_{t}+0.00 B D_{t}+U_{10 t}
\end{aligned}
$$

In given Equation (6), (10) the interest rate and bank deposits coefficient are zero i.e. $\beta_{11}=$ $\alpha_{11}=\alpha_{12}=0$ this is because there probability value is greater than 50 percent which is highly insignificant. In equation (7), when an investment goes up by 1 SD, therefore consumption goes up by 0.263 SD. Practically when investment increase leads to rises output of the economy people have more money comes up, to spend more and more on consumption. 
Equation (8) shows that when interest rate increase by 1 SD, price of equity goes down by 0.238 SD. Therefore, an increase interest rate the consumer and businesses spending and their earning decrease its results the price of equity also reduced. Equation (9) shows that, when the interest rate goes up by 1 standard deviation, industrial inputs prices go up by 0.216 standard deviations. The rise an interest rate will put positive pressure on industrial inputs prices its effect on the cost of production increases.

$$
\begin{aligned}
& I_{t}=-0.605 I R_{t}+0.120 L N_{t}+0.00 P_{e q}+U_{11 t} \\
& Y_{t}=0.00 E X P_{t}+0.944 C_{t}+0.151 I_{t}-0.112 I I P_{t}+U_{12 t}
\end{aligned}
$$

Equation (11) shows that $1 \mathrm{SD}$ change interest rate will reduce the investment by $0.605 \mathrm{SD}$. We know that if the interest rate increase the cost of borrowing and capital increase lead to reduced investment. The coefficient has positive with significant coefficient such that 0.120 SD rise investment due to increase $1 \mathrm{SD}$ increase loan. The coefficient of the price of equity is zero i.e. $\alpha_{23}=0$ because they have highly insignificant their probability value more than 50 percent. Equation (12) shows that, the exports coefficient has zero i.e. $\alpha_{41}=0$. When $1 \mathrm{SD}$ change in consumption lead to rise output by 0.944 SD. According to Piana other thing being constant when consumption increase the same amount output have raises. Moreover, when 1 SD change in investment leads to increase output by 0.151 SD, when investment increase the output is also increasing in economy. Finally, if industrial inputs prices 1 SD rises there lead to reduced output by $0.112 \mathrm{SD}$.

$$
\begin{aligned}
& I N F_{t}=0.180 E R_{t}+0.246 P I_{t}+0.234 P E_{t}+0.00 E X P_{t}+0.00 B D_{t}-0.171 I_{t}+ \\
& +0.299 C_{t}+0.00 P e q_{t}-0.198 L N_{t}+0.235 I I P_{t}-0.308 Y_{t}+U_{13 t}
\end{aligned}
$$

In the given equation (13) shows that the exchange rate has a significant effect on Inflation in Pakistan. The coefficient has a positive value is 0.180 , one SD increase in the exchange rate will increase the price level by $0.180 \mathrm{SD}$. when the exchange rate increase the imported goods are more expensive. If imported goods like (production inputs, oil, etc.) more costly, then increase the domestic prices due to utilizing this imported goods in the production process its results inflation have also increased. The coefficients of the price of imports and the price of exports have positive, there for 1 unit increase the price of imports and the price of exports the inflation have come up by 0.264 and 0.234 SD respectively. If the price of imports and the price of export rise the production will be reduced therefore inflation has occurred.

The exports (EXP), bank deposits (BD) and price of equity (Peq) coefficients $\alpha_{43}=\alpha_{44}=$ $\alpha_{47}=0$, this is because their probability value is greater than 50 percent which is highly insignificant. The sign of the variable investment shows that there is a negative relationship between investment and inflation. If $1 \mathrm{SD}$ increase an investment the inflation has reduced by $0.171 \mathrm{SD}$. The increase in investment reveals to rising employment and output level in the economy there for reduced inflation. A positive sign of consumption indicates a positive relationship between consumption and inflation. If 1 SD increase in consumption the inflation have raised by 0.299 SD. When consumption rises, the consumer demand more than the producer's ability to produce the goods and services, therefore prices exceeds. If this carries on, it makes inflation. The coefficient of loan has a negative sign if 1 SD increase loan the 
inflation has reduced by 0.198 SD it is not true economically. When industrial inputs price goes up by 1 SD, inflation goes up by 0.235 SD. The industrial inputs prices rise the cost of production, therefore, output level decreases its results inflation have increased. The output has a significant coefficient, the negative sign reveals that, if 1 SD increase output level in the economy, the inflation has reduced by 0.308 SD.

\section{CONCLUSION}

This empirical study examines what determine Inflation in Pakistan? An Investigation through Structural Equation Modeling by using time series data for a period from 1975 to 2017. We have check variables for stationarity through ADF test. The ADF test shows that Money supply (MS), interest rate (IR), Exchange rate (ER), Price of imports (PI), Price of Export $(\mathrm{PE})$, exports (EXP), consumption (c), Bank Deposits (BD), loan (LN), Output (Y), Price of equity (Peq), and Industrial inputs prices (IIP), are not stationary at level such that; I (1), while Investment (I), and inflation (INF) are stationary at level i.e. I (O). The result of unrestricted structural regression model (USEM) few coefficients are insignificant, there probability value in more than 50 percent. The RSEM estimated results reveal that; interest rate has a positive relation with exchange rate and industrial inputs prices, while negative relation with the price of equity and investment. Therefore, the exchange rate, price of imports, price of exports and consumption have a positive relation with inflation while investment, loan, and output have a negative relationship with inflation. Finally, the interest rate is not a significant determinant of inflation. Therefore, the exchange rate and cost channel are responsible for the transmission mechanism of interest rate to inflation in Pakistan.

\section{Policy Recommendation}

The interest rate is not a significant determinant of inflation. Therefore, the exchange rate and cost channel are responsible for the transmission mechanism of interest rate to inflation in Pakistan. The finding supports the finding of the [6] who also found that interest rate to control inflation is useless. On the other hands they affect investment, and growth rate negatively. To control inflation the policy of high-interest rate should be avoided.

\section{Future Research}

Just like every other research opens up new avenues for future work, this study too can be extended in several ways. First, this study focus on how monetary policy effect inflation, further includes in this study fiscal policy. Lastly, a regional analysis can serve as the best extension of this research. Our work was focused on Pakistan only, however a regional comparison can be appropriate. Provided that the child inflation rate of developing Asian countries including India and Bangladesh is also high, thus comparison using data from WDI could provide some useful insights. 


\section{REFERENCES}

3. Anning, L., Tuama, A. S., \& Darko, S. (2017). Inflation, unemployment and economic growth: evidence from the var model approach for the economy of Iraq. International Journal of Developing and Emerging Economies, 5 (1), 26-39.

4. Arif, K. M., \& Ali, M. M. (2012). Determinants of Inflation in Bangladesh: An Empirical Investigation. Journal of Economics and Sustainable Development, 12 (3), 9-17.

5. Asad, I., Ahmad, N., \& Hussain, Z. (2012). Impact of real effective exchange rate on inflation in Pakistan. Asian Economic and Financial Review, 8 (2), 983-990.

6. Asghar, N., Jaffri, A. A., \& Asjed, R. (2013). An empirical investigation of domestic and external determinants of inflation in Pakistan. Pakistan Economic and Social Review, 51 (1), 55-70.

7. Atgbr, M., \& Altay, N. O. (2017). Examination of the exchange rate and interest rate channels of the monetary transmission mechanism during the inflation targeting: Turkey and Mexico countries examples. Theoretical and Applied Economics, Asociatia Generala a Economistilor din Romania - AGER, O(4(613), W), 137-160.

8. Rehman. (2014). Relationship Between Energy Prices, Monetary Policy and Inflation; A Case Study of South Asian Economies. Journal of Central Banking Theory and Practice, 3 (1), 43-58. https://doi.org/10.2478/jcbtp-2014-0004

9. Said Ayubu, V. (2013). Monetary Policy and Inflation Dynamics : An empirical case study of Tanzanian economy (Dissertation). Retrieved from http://urn.kb.se/resolve?urn =urn:nbn:se:umu:diva-79684

10. Bartolo, A.D. (2000). Human Capital Estimation through Structural Equation Models with some Categorical Observed Variables.

11. Bashir, F., Yousuf, F., \& Aslam, H. (2016). Determinants of Inflation in Pakistan: Demand and Supply Side Analysis. Journal of Finance \& Economic Research, 1(1), 43-57. https:// doi.org/10.20547/jfer1601105

12. Bawa, S., Abdullahi, I. S., \& Ibrahim, A. (2016). Analysis of Inflation Dynamics in Nigeria (1981 - 2015), 7(1), 22.

13. Bebczuk, R. N. (2009). productivity and saving channels of economic growth as latent variables: an application of confirmatory factor analysis. Estudios de Есопотна, 27, 15.

14. Chaudhary, M. A., \& Ahmad, N. (1995). Money Supply, Deficit, and Inflation in Pakistan. The Pakistan Development Review, 34 (4III), 945-956. https://doi.org/10.30541/ v34i4IIIpp.945-956

15. Chaudhry, I. S., Akhtar, M. H., Mahmood, K., \& Faridi, M. Z. (2011). Foreign Exchange and Inflation in Pakistan: Evidence from ARDL Modelling Approach. International Journal of Economics and Finance, 3 (1). https://doi.org/10.5539/ijef.v3n1p69

16. Chaudhry, I. S., Ismail, R., Farooq, F., \& Murtaza, G. (2005). Monetary policy and its inflationary pressure in Pakistan. Pakistan Economic and Social Review, 53 (2), 251-268.

17. Choudhri, E. U., Jan, A., \& Malik, H. (2015). Monetary Policy in Pakistan: Effectiveness in Inflation Control and Stabilization, 37. S-37204-PAK-1

18. Choudhry, I., Hasan, M., \& Ali, M. (2015). The Relationship between Exports of Food 
Items and Inflation (CPI): Case Study of Pakistan, 4, 7.

19. Fatima, N., \& Sahibzada, S. A. (2012). Empirical Evidence of Fisher Effect in Pakistan, 4.

20. Ghaffari, \& Rehman. (2016). Failure of interest based monetary policy: evidences from selected Islamic and non-Islamic countries. Pakistan business review, 17 (4), 731-753. DOI: http://dx.doi.org/10.22555/pbr.v17i4.549

21. He, Y. (2017). A Study on the Relationship between Money Supply and Macroeconomic Variables in China. Mediterranean Journal of Social Sciences, 8 (6), 99-107. https://doi. org/10.1515/mjss-2017-0046

22. Hussain, S., \& Malik, S. (2011). Inflation and Economic Growth: Evidence from Pakistan. International Journal of Economics and Finance, 3 (5). https://doi.org/10.5539/ijef. v3n5p262

23. Ihsan, I., \& Anjum, S. (2013). Impact of Money Supply (M2) on GDP of Pakistan. Global Journal of Management and Business Research Finance, 13 (6). Retrieved from https:// journalofbusiness.org/index.php/GJMBR/article/view/999

24. Jalees, D. T. (2014). A Structural Equation Model, (1), 9.

25. Jaradat, D. M. A., \& Al-Hhosban, S. A. (2014). Relationship and causality between interest rate and inflation rate case of Jordan, 6 (4), 12.

26. Javed, Z. H., Farooq, M., Hussain, M., Shezad, A.-R., Iqbal, S., \& Akram, S. (2011). Impact of Cost-Push and Monetary Factors on GDP Deflator: Empirical Evidence from the Economy of Pakistan. International Journal of Financial Research, 2(1). https://doi. org/10.5430/ijfr.v2n1p57

27. Khan, R. E. A., \& Gill, A. R. (2007). Impact of Supply of Money on Food and General Price Indices: A Case of Pakistan. IUB J. Social. Sci. Humanit., 5.

28. Khan, R. E. A., \& Gill, A. R. (2010). Determinants of Inflation: A Case of Pakistan (19702007). Journal of Economics, 1 (1), 45-51. https://doi.org/10.1080/09765239.2010.11 884923

29. Khan, S. U., \& Saqib, O. F. (2011). Political instability and inflation in Pakistan. Journal of Asian Economics, 22 (6), 540-549. https://doi.org/10.1016/j.asieco.2011.08.006

30. Kibria, U., Mehmood, Y., Kamran, M., Arshad, M. U., Perveen, R., \& Sajid, M. (2014). The Impact of Macroeconomic Variables on Stock Market Returns: A Case of Pakistan. Research Journal of Management Sciences, 8 (3), 1-7.

31. Malik, A. (2016). The Impact of Oil Price Changes on Inflation in Pakistan. International journal of energy economics and policy, 6 (4), 727-737.

32. Memon, P. A., \& Ghumro, N. H. (2014). Impact of Monetary and Fiscal Policies on Pakistan's Economy using Vector Autoregressive Model. International SAMANM Journal of Finance and Accounting, 4 (2), 35-50.

33. Mukras, M. S., \& Gedion Momanyi, D. (2016). The Determinants of Inflation in the Kenyan Economy. International Journal of Economics, 1, 16.

34. Musa, A. M. A., \& Yousif, F. M. K. (2018). Modeling the determinants of inflation in Sudan using generalized method of moments for the period 2000-2017. International Journal of Information Research and Review, 5 (2), 5154-5165.

35. Nawaz, M., Naeem, M., Ullah, S., \& Khan, S. U. (2017). Correlation and Causality between Inflation and Selected Macroeconomic Variables: Empirical Evidence from Pakistan 
(1990-2012). IBusiness, 09 (04), 149-166. https://doi.org/10.4236/ib.2017.94011

36. Noor, A., \& Chaudhary, M. A. (2009). Economic Management and Roots of Inflation in Pakistan. Forman Journal of Economic Studies, 5, 17-34.

37. Ozsahin, S., \& Ucler, G. (2017). The Consequences of Corruption on Inflation in Developing Countries: Evidence from Panel Cointegration and Causality Tests. Economies, 5(4), 49. https://doi.org/10.3390/economies5040049

38. Pietrzak, M. B. (2017). Structural equation modeling of regional economic development in polish voivodeships in the years 2010-2014. The 11th International Days of Statistics and Economics, Prague, September 14-16.

39. Raheem Ahmed, R., Vveinhardt, J., Streimikiene, D., Ghauri, S. P., \& Ahmad, N. (2017). estimation of long-run relationship of inflation (cpi \& wpi), and oil prices with kse-100 index: evidence from johansen multivariate cointegration approach. Technological and Economic Development of Economy, 23 (4), 567-588. https://doi.org/10.3846/202949 13.2017.1289422

40. Ratnasiri, H. (2011). The Main Determinants of Inflation in Sri Lanka: A VAR based Analysis. Staff Studies, 39 (1), 1. https://doi.org/10.4038/ss.v39i1.3151

41. Saleem, F., Haider, Z., Shoukat, S., Shafiq, S., Zahid, A., Shahzad, A., \& Hassan, W. (2013). Determinants of inflation in Pakistan. Interdisciplinary Journal of Contemporary Research in Business, 9 (4), 245-252.

\section{INFORMATION ABOUT THE AUTHOR}

Ijaz Uddin (Pakistan, Matta Swat) - Student, MPhil or MS Econometrics. Pakistan Institute of Devolvement Economics (Islamabad, Pakistan). E-mail: ijazuddin01@gmail.com

\section{OPEN 2 ACCESS}

Available: https://statecounsellor.wordpress.com/2020/12/01/uddin/

Received: Sep 13, 2020 | Accepted: Nov 15, 2020 | Published: Dec 1, 2020

Editor: Mohamed R. Abonazel, PhD in Statistics and Econometrics. Cairo University, EGYPT

Copyright: ( 2020 Uddin, I. This is an open access article distributed under the terms of the Creative Commons

Attribution License, which permits unrestricted use, distribution, and reproduction in any medium, provided the original author and source are credited.

Competing interests: The authors have declared that no competing interests exist. 